\title{
PReS-FINAL-2263: Progressive pseudorheumatoid dysplasia in differential diagnosis of juvenile idiopathic arthritis
}

\author{
E Vrtíková' ${ }^{*}$, E Košková1, M Genčík², J Sedlákova ${ }^{1}$ \\ From 20th Pediatric Rheumatology European Society (PReS) Congress \\ Ljubljana, Slovenia. 25-29 September 2013
}

\section{Introduction}

In the differential diagnostics of juvenile idiopathic arthritis (JIA), rare genetic diseases that often mimic chronic polyarthritis, should be considered. In our case report we describe such rare disease - progressive pseudorheumatoid dysplasia (PPD).

\section{Objectives}

A 13 year old female patient started to complain about lower extremity pain at the age of 3 years, refuted to walk, and the walking stereotype has been disrupted. She has been seen at our rheumatology practice at the age of 7 year. Our findings included a baby thickening and rigidity of the proximal interphalangeal joints of the hands, a substantial deficit in hip function, valgus deformities of knees and ankles with painless movement limitation, restriction of the cervical spine function and signs of thoracic kyphosis. Arthrology and X-ray hands examination suggested a polyarticular form of JIA. Blood examination did not show increased inflammatory activity and the platyspondyly shown on the spine $\mathrm{X}$-Ray was also discrepant. Given the atypical clinical representation, we consider Mucopolysaccharidosis which has been excluded by repeated targeted examination. Given the progressive functional deficit, development of erosive changes in the hip joint shown by X-ray and ultrasound examinations, immunosuppressive therapy has been administered for 6 months. After 7 years of disease duration a small effusion in the knee joints appeared. Cytological examination, however, showed non-inflammatory features of the synovial fluid. Based on these findings and the overall course of the disease,

${ }^{1}$ National Institute of Rheumatic Diseases, Pieštany, Slovakia

Full list of author information is available at the end of the article we revised our diagnosis to progressive pseudorheumatoid dysplasia (PPD). Molecular genetic testing showed the splicing mutation c. 589 of the WISP3 gene, which is associated with this autosomal recessive skeletal disease. Subsequently we found consanguinity in parents of our patient. WISP3 gene plays a role in the cartilage growth and homeostasis. PPD is spondyloepiphyseal dysplasia characterized by progressive arthropathy, recessive inheritance mode and a prevalence of one in 1 million. First symptoms usually appear before the age of 8 years. Problems typically start as muscle weakness and symmetrical swelling of PIP joints of hands. Thereafter during the course of disease a limitation of joint mobility, articular deformities and pain, accentuation of lumbar lordosis and thoracic kyphosis and/or scoliosis each gradually occur. Affected individuals have normal facial appearance and their intellectual capacity is not affected. PPD diagnosis is based on clinical and X-ray findings. Immunosuppressive therapy is not effective but rehabilitation has an irreplaceable role. The disease does not affect life expectancy; its progressive character often requires joint replacement in the early adult. The disorder may be mistakenly diagnosed as JIA; however X-ray findings (platyspondyly, generalized epiphyseal dysplasia) and absence of inflammatory joint involvement are not typical for JIA.

\section{Methods}

Case report.

\section{Results}

Atypical clinical presentation with laboratory and imaging results should indicate revision of the original diagnosis. 


\section{Conclusion}

In rheumatology practice the delay in correct diagnosis and unfortunate indication of long-term not indicated immunosuppressive treatment may not always be avoided.

\section{Disclosure of interest}

None declared.

\section{Authors' details}

${ }^{1}$ National Institute of Rheumatic Diseases, Pieštany, Slovakia. ${ }^{2}$ Medgene s.r.o., Bratislava, Slovakia.

Published: 5 December 2013

doi:10.1186/1546-0096-11-S2-P253

Cite this article as: Vrtíková et al:: PReS-FINAL-2263: Progressive pseudorheumatoid dysplasia in differential diagnosis of juvenile idiopathic arthritis. Pediatric Rheumatology 2013 11(Suppl 2):P253.

Submit your next manuscript to BioMed Central and take full advantage of:

- Convenient online submission

- Thorough peer review

- No space constraints or color figure charges

- Immediate publication on acceptance

- Inclusion in PubMed, CAS, Scopus and Google Scholar

- Research which is freely available for redistribution

Submit your manuscript at www.biomedcentral.com/submit
Ciomed Central 